\title{
Intellectual Property Protection in Field of Information Technology
}

\author{
Perepechko L.N. \\ Department of Innovation, Application-Oriented, and \\ Foreign Economic Activities \\ Kutateladze Institute of Tehrmophysics SB RAS \\ Novosibirsk, Russia \\ e-mail:1udmila@itp.nsc.ru
}

\author{
Sharina I.A. \\ Department of Innovation, Application-Oriented, and \\ Foreign Economic Activities \\ Kutateladze Institute of Tehrmophysics SB RAS \\ Novosibirsk, Russia \\ e-mail: sharina@itp.nsc.ru
}

\author{
Rakhmanova A.R. \\ Department of Innovation, Application-Oriented, \\ and Foreign Economic Activities \\ Kutateladze Institute of Tehrmophysics SB RAS \\ Novosibirsk, Russia \\ e-mail: rakhmanova@itp.nsc.ru
}

\begin{abstract}
Since the second half of the 20th century, with the development of the Internet, globalization of markets, and the emergence of multinational companies in the world, there are "patent race" and "innovation race," that is an increase in the number of patents associated with a rapid increase in the production of innovative (high-tech) products. Development and supply of products in the field of information technology is becoming one of the most profitable items of the Russian export. Software protection in Russia is growing rapidly, but is executed within the frameworks of copyrights, what gives no protection for the algorithm, which provides new methods and technical solutions, often having great commercial value. At the same time, protection of inventions in information technology in the field of information processing, modeling of physical processes, and system control is much more promising for concluding licensing agreements and receiving income from granting rights to use these inventions.
\end{abstract}

Keywords—intellectual property; invention; softwaree; protection

\section{INTRODUCTION}

The concept of long-term socio-economic development of the Russian Federation for the period up to 2020 determined the fundamental task of the transition of Russian economy from export-raw to an innovative socially oriented type of development, which is inseparably linked with the creation, dissemination and use of new knowledge in the field of science and technology, as well as with the market of intellectual property (IP).

At the moment, Russia as a participant of the global process of innovative economic development is improperly holding a low position among other technologically advanced countries that does not comply with its high scientific and technical potential and is due to a small proportion of hightech products in exports and a small volume of the IP market. Accordingly, there is a strategically important problem, formulated at the state level - to eliminate the discrepancy between significant volumes of generated new knowledge in the field of science and technology and low efficiency of their use in the economy.

Since the second half of the 20th century, with the development of the Internet, globalization of markets, and the emergence of multinational companies in the world, there are "patent race" and "innovation race," an increase in the number of patents associated with a rapid increase in the production of innovative (high-tech) products. In the 21st century, intellectual property (IP) is becoming a commodity in the market of innovative products, forming the fourth basket of goods along with goods, works and services [1]. The intellectual property market shows a faster growth compared with that of the gross domestic product (GDP), manufacturing and exports of high-tech products. According to the World Bank data from 2001 to 2015, the gross global product (GGP) increased 2.17 times in current prices, the total high-tech exports -1.04 times, revenues from IP - 3.36 times, and payments for IP -4.46 times. The IP market in 2015 was about $2 / 3$ of the market of high-tech exports (660 and about 1000 billion U.S. dollars, respectively), that is these values have become almost of the same order. Moreover, the maximum growth of the IP market was at the end of the 20th century: revenues from royalties and license fees accounted for 2.8 billion USD in 1970, 27 billion USD in 1990 (10-time increase for 20 years) and 180 billion US dollars in 2009 (an increase of 6.7 times for 20 years). Intellectual property is one of the most valuable assets in commercial transactions. The brand value of world famous companies is estimated at billions of dollars. In 2011, the most highly valued brands 
were: Google - 44.3 billion US dollars, Microsoft -42.8 bln USD, Wal-Mart - 36.2 bln USD, IBM - 36.2 bln USD, and Vodafone -30.8 bln USD [2].

\section{TENDENCIES AND FEATURES OF INTELLECTUAL PROPERTY PROTECTION}

Russia consistently every year is ranked in the top ten in the world for the number of patents for inventions, issued to the country residents. In 2014, Russia ranked 6th for patent applications (including inventions and utility models), 8th - for trademark applications, 15th - for applications for industrial designs, and 8th - for the number of patents maintained in force [3].

However, there are features of IP protection peculiar to Russian residents, protecting IP predominantly in the territory of their country similar to the representatives of other developing countries (of 28.7 thousand applications for inventions filed in 2013 only 5 thousand were filed through international procedures to Rospatent).

Intellectual property owned by the country residents and protected abroad is an indicator of availability of high technologies with export potential.

The effectiveness of the national innovation system is measured on the basis of patent statistics [4]. The analysis based on the number of patents provides results that are consistent with other more or less direct measurement of innovations [5]; this allows considering the growth rate of patents as a valid indicator of changes in the innovation superiority. Furthermore, the use of data from the European Patent Office and USPTO for comparative analysis has become a common practice both in policy documents $[6,7]$ and in academic research [8]. The total number of patents is an important indicator, but in itself it cannot be a measure of innovation [9], since intellectual property is associated with technological and social capital, science, industry, human resources [10-12] and investments in R \& D [13-15].

In Russia, except for the lag in patenting inventions abroad, there is another feature of IP protection: innovations in the field of software and computer modeling in Russia are mostly protected as computer programs and databases that are the "object" of copyright. And when, for example, the computing algorithm is transformed to a different programming language, they stop being the object of protection.

Meanwhile the global trend is to extend the protection areas, to protect inventions and other IP objects in other countries, and to protect software and computational algorithms as inventions, which is associated with the protection of exported products, the suppression of unfair competition and the opportunity to receive revenues from IP exports.

Accordingly, the IP market in Russia is less than $1 \%$ of the world market (according to the World Bank) and only a fraction of a percent of GDP. World leaders in the IP protection, its dynamics and the scope of the protection areas are the USA, China and Japan.
Priorities of patenting in different countries are discernible in the technologies (TABLES I, II and III).

TABLE I. DISTRIBUTION OF PATENT APPLICATIONS BY TECHNOLOGY (FROM 2000 TO 2014) IN THE USA

\begin{tabular}{|l|c|}
\hline \multicolumn{1}{|c|}{ Technology } & Percentage, \% \\
\hline Computer technology & 11.11 \\
\hline Medical technology & 8.05 \\
\hline Pharmaceuticals & 6.27 \\
\hline Digital communication & 4.87 \\
\hline Electrical equipment, hardware, energy & 4.30 \\
\hline Organic fine chemistry & 4.07 \\
\hline Biotechnology & 3.93 \\
\hline Measurement & 3.92 \\
\hline Semiconductors & 3.54 \\
\hline Communication & 3,51 \\
\hline Other & 46,43 \\
\hline
\end{tabular}

TABLE II. DISTRIBUTION OF PATENT APPLICATIONS BY TECHNOLOGY (FROM 2000 TO 2014) IN CHINA

\begin{tabular}{|l|c|}
\hline \multicolumn{1}{|c|}{ Technology } & Percentage, \% \\
\hline Digital communication & 6.72 \\
\hline Electrical equipment, hardware, energy & 6.69 \\
\hline Computer technology & 6.22 \\
\hline Measurement & 5.82 \\
\hline Pharmaceuticals & 5.49 \\
\hline Materials, metallurgy & 4.41 \\
\hline Basic materials, chemistry & 4.20 \\
\hline Machines & 3.97 \\
\hline Food chemistry & 3.95 \\
\hline Civil engineering & 3.85 \\
\hline Other & 48.68 \\
\hline
\end{tabular}

For the U.S.A., patenting of computer technologies holds the largest share, which is understandable, since the patent law of the USA does not specifically stipulate the exclusion of software or working methods from patentable objects. In the USA, any object that provides a "useful, concrete and tangible result" is considered patentable.

In Russia, computer technologies are patented so seldom that they do not even fall within the top 10 (TABLE III).

TABLE III.

DISTRIBUTION OF PATENT APPLICATIONS BY TECHNOLOGY (2000-2014) IN RUSSIA

\begin{tabular}{|l|c|}
\hline \multicolumn{1}{|c|}{ Technology } & Percentage, $\%$ \\
\hline Food chemistry & 10.52 \\
\hline Medical technology & 8.25 \\
\hline Measurement & 6.93 \\
\hline Civil engineering & 6.66 \\
\hline Other specialized machines & 5.88 \\
\hline Materials, metallurgy & 5.83 \\
\hline Engines, pumps, turbines & 4.98 \\
\hline Transport & 4.37 \\
\hline Pharmaceuticals & 4.23 \\
\hline Machines & 3.75 \\
\hline Other & 38.60 \\
\hline
\end{tabular}


As for China, one may state that politics in this country has been a decisive factor in the increase of patents in the field of computer technology over the past 10 years, as indeed in many other areas of technology.

Meanwhile in recent years, Russian exports of software (SW) have been booming. According to the data of the noncommercial partnership "RUSSOFT", for seven years their volume has grown almost threefold from 2.7 billion USD in 2009 to 7.6 bln USD in 2016. Thus, the information technology (IT) has been irreversibly becoming one of the most profitable items of the Russian export as a whole. If the present trend continues, SW supply overseas will be commensurable with the supply of weapons, which is at present only twice the volume of supply of IT products. The bulk of sales of Russian software abroad fall on the United States and the European Union (Germany, Scandinavia, Central and Eastern Europe). However, the noticeable is the sales growth in other areas - China, Southeast Asia, South America, Australia, and the Middle East.

Russian IT companies supply a wide range of products and services abroad. In particular, the exports are growing in the field of information security, mobile applications, navigation and geographic information systems, as well as document management systems; custom software development to fit the needs of specific companies is advancing as well. The successful development of the Russian software export is determined by several factors. First of all, this is a high level of Russian specialists and a low exchange rate of rouble [16].

In TABLE IV, there is the dynamics of filing applications for registration of computer programs, databases and topologies of integrated circuits in Federal districts of RF in 2006-2011.

In TABLE $\mathrm{V}$, there is the dynamics of filing applications for industrial property objects to Rospatent in 2006-2011.

TABLE IV. DYNAMICS OF FILING APPLICATIONS FOR REGISTRATION OF COMPUTER PROGRAMS, DATABASES AND TOPOLOGIES OF INTEGRATED CIRCUITS IN FEDERAL DISTRICTS OF RF IN 2006-2011

\begin{tabular}{|l|l|l|l|l|l|l|}
\hline $\begin{array}{c}\text { Federal } \\
\text { districts }\end{array}$ & $\mathbf{2 0 0 6}$ & $\mathbf{2 0 0 7}$ & $\mathbf{2 0 0 8}$ & $\mathbf{2 0 0 9}$ & $\mathbf{2 0 1 0}$ & $\mathbf{2 0 1 1}$ \\
\hline Central & 2270 & 2742 & 3248 & 3850 & 4473 & 5220 \\
\hline Privolzhsky & 771 & 860 & 895 & 1074 & 1244 & 1533 \\
\hline North-West & 495 & 566 & 663 & 894 & 1008 & 1308 \\
\hline South & 494 & 638 & 870 & 935 & 1031 & 1211 \\
\hline Siberian & 450 & 493 & 555 & 735 & 853 & 1257 \\
\hline Ural & 327 & 373 & 407 & 462 & 455 & 591 \\
\hline Far East & 127 & 150 & 125 & 187 & 199 & 250 \\
\hline Total & $\mathbf{4 9 3 4}$ & $\mathbf{5 8 2 2}$ & $\mathbf{6 7 6 3}$ & $\mathbf{8 1 3 7}$ & $\mathbf{9 2 6 3}$ & $\mathbf{1 1 3 7 0}$ \\
\hline
\end{tabular}

It is also worth noting the number of registered computer programs and databases (TABLE IV) that has increased in the last decade, and which growth rate is overtaking the dynamics of the protection of industrial property objects (IPO) (TABLE $\mathrm{V}$ ); interestingly, the Siberian Federal district (SFD) shows the highest growth of this indicator.
TABLE V.DYNAMICS OF FILING APPLICATIONS FOR INDUSTRIAL PROPERTY OBJECTS TO ROSPATENT IN 2006-2011

\begin{tabular}{|l|l|l|l|l|l|l|}
\hline $\begin{array}{c}\text { Type of } \\
\text { IPO }\end{array}$ & $\mathbf{2 0 0 6}$ & $\mathbf{2 0 0 7}$ & $\mathbf{2 0 0 8}$ & $\mathbf{2 0 0 9}$ & $\mathbf{2 0 1 0}$ & $\mathbf{2 0 1 1}$ \\
\hline Invention & 37691 & 39439 & 41849 & 38564 & 42500 & 41414 \\
\hline $\begin{array}{l}\text { Utility } \\
\text { model }\end{array}$ & 9699 & 10075 & 10995 & 11153 & 12262 & 13241 \\
\hline $\begin{array}{l}\text { Industrial } \\
\text { design }\end{array}$ & 4385 & 4823 & 4711 & 3740 & 3997 & 4197 \\
\hline $\begin{array}{l}\text { Trademark } \\
\text { and } \\
\text { service } \\
\text { mark }\end{array}$ & 52984 & 57262 & 57112 & 50107 & 56848 & 59717 \\
\hline Total & 104759 & 111599 & 114667 & 103564 & 115607 & 118569 \\
\hline
\end{tabular}

As can be seen from TABLE IV and V, the exports of industrial designs and the number of computer programs and databases registered with Rospatent are growing in Russia.

In Siberian Branch of Russian Academy of Science, the number of protected computer programs and databases has grown significantly (Table VI) since 1999, which confirms the general trend of protection of this type of IP in Russia. It is the evidence of the development of information technology and the need to protect inventions in this field.

Notations (Table VI): 1 - Granted patents on Inventions, 2 - Granted patents on Utility models, 3 - Granted patents on Industrial designs, 4 - Registered Trademarks and service mark, 5 - Registered computer programs, 6 - Registered Databases, 7 - Registered "know-how".

\section{TABLE VI. THE STRUCTURE OF THE IP OF THE SB RAS IN} 1999 AND 2013

\begin{tabular}{|c|c|c|c|c|c|c|c|}
\hline Year & $\mathbf{1}$ & $\mathbf{2}$ & $\mathbf{3}$ & $\mathbf{4}$ & $\mathbf{5}$ & $\mathbf{6}$ & $\mathbf{7}$ \\
\hline 1999 & 245 & 9 & 0 & 0 & 4 & 3 & 9 \\
\hline 2013 & 291 & 51 & 2 & 1 & 99 & 20 & 20 \\
\hline
\end{tabular}

Computer programs and databases are registered and protected in Rospatent as the copyright objects. According to the Civil Code of the Russian Federation, part 4 of article 1261 "A computer program is the totality of data and commands, presented in objective form and designed for operating computers and other computing devices in order to obtain a certain result, including preparatory materials received during development of a computer program, and the resulting audio-visual images."

Thus, copyright protects only the original text (code) and audio-visual materials, but gives no protection for algorithm, which provides new methods and technical solutions, often having great commercial value.

By itself, the source code of the computer program is easy enough to change, and any change in this code is already a new object of copyright, requiring registration, so the copyright certificate only formally confirms the applicant's rights, and the real degree of protection of these rights is extremely low.

Of course, for authors and applicants the level of protection of the created intellectual property object is of paramount interest; so, arises the question of protection of computer program as the object of industrial property, which it 
fails to appear according to the Civil Code of the Russian Federation, part 4 of article 1350, paragraph 5.

\section{RECOMMENDATIONS FOR THE PROTECTION OF INTELLECTUAL PROPERTY IN THE FIELD OF INFORMATION TECHNOLOGY}

In recent years, patent professionals propose to implement comprehensive protection of computer programs by registering their individual components, namely the code as an object of copyright, the algorithm as an invention, the interface as an industrial design, and the logo as a trademark.

According to the Civil Code of the Russian Federation, part 4 of article 1350, item 1 "the invention subject to protection is a technical solution in any field, relating to a product (in particular, device, substance, strain of microorganism, cell culture of plants or animals) or a method (process of implementing actions over a material object by material means)".

Hence, the algorithm may be patented, for example, as a method of information processing, modeling of physical processes, and system control. The main criteria are the presence of a material object, material means, the order of steps (stages) in time and the technical result. In other words, the physical object is subjected to a certain sequence of actions using the material means with the aim of obtaining the technical result.

According to the Administrative regulations of the Federal Service for Intellectual Property, the features of the invention relating to the method are as follows: a sequence of actions (methods, operations) over the physical object, modalities of actions, specific conditions (temperature, pressure, etc.), used material means (devices, substances, strains, etc.).

Let us consider examples of the analysis of algorithms in the field of IT-technologies and modelling of physical processes.

1) RF Patent No. 2586249 for the invention "Method of search query processing and server." Patentee: "Yandex" Ltd.

The general description (limiting part of claim) is:

The method of processing a search query from a user, associated with the electronic device, and generating a set of search results in response to search query; the method is realized on a search server connected to the electronic device via the data network.

Field of the invention: information search, namely the processing of user's search query and creating a set of search results corresponding to the search query.

Technical result: providing the user with various components of the search object relevant to the search object, based on determining the user's intent.

The objects of the method are:

- material objects: the server, a display;

- material means: an electronic device, the data transmission network;
- virtual objects, describing the process of query processing: the search query, a set of the search results, the component of the search object, the most appropriate search result, added with the component of the search object, the search results page.

The usage of devices is:

- data input using the electronic device;

- data transmission through a network;

- implementation of the process on the server under the control of the program code;

- displaying results on the display.

The order of steps (stages) in time is:

1. Receiving a search query from an electronic device via a data network.

2. Processing the search query:

- defining a set of search results based on the search query;

- defining the 1st component of a search object associated with the search query;

- determining the most appropriate search result from the set of search results associated with the component of the search object;

- creating the added component of the search object by adding the component of the search object with the reference to the most suitable search result;

- preparing the search results page that includes the added component of the search object.

3. Response to the search query:

- initiating displaying of the search results page by an electronic device.

2) RF Patent No. 2530710 for the invention "Method of mathematical and computer modeling". Patentee: JSC "558 ARP".

The general description (limiting part of the claim) is:

The method of mathematical and computer modeling, involving the creation of a hierarchical model.

Technical field is: the invention refers to modelling and can be used to create a model of the behavior of structures and products of aviation technology in the conditions of uncertainty of input parameters.

Technical result: an increase of accuracy of tests of mechanical and performance properties of the developed and rebuilt units and parts.

The objects of the method:

- material objects: a computer, a display;

- material resources: an electronic device, a data network, the machine-readable medium (executable 
computer programs), which makes the computer to perform the steps of the method;

- virtual objects: model body (microscopic model).

The usage of devices:

- data input using the electronic device;

- data transmission through a network;

- implementing simulation under the control of computer-readable media (executable computer programs);

- displaying results on the display.

The order of steps (stages) in time is:

1. Data input through the electronic device.

2. Creating a model of the sample behavior at the microscopic level by finite-element modeling.

- Creating (generating by computer) the sample (model body), which is geometrically similar to standard samples used for the macroscopic mechanical tests, in accordance with the preset experimental parameter values.

- Computer simulation according to the set program of real sample testing and obtaining input parameters for finite element modeling.

- Finite element modeling and defining the set of mechanical parameters determinant for the sample behavior.

3. Creating a model of the behavior of structures and products at the macroscopic level by the methods of quantum mechanics and molecular dynamics.

4. Displaying the results on a display.

As it is seen in the above-mentioned examples, the features of objects correspond to the features of the invention, defined in Administrative regulations of the Federal Service for Intellectual Property.

Examples of inventions in the field of computer technology may be:

1. a medium of program storage that, when executed on the computer causes the processor to perform steps of a method (provided that the method is a technical solution);

2. a computer-readable medium for storing a computer program to execute a computer method of data processing comprising the steps;

3. the method of information output, implying the program execution on the server of the server center that generates and streams the user's page in the form of interactive streaming video on the user's customer display connected to the server via the Internet, etc.
These algorithms meet the above criteria. They were patented as industrial property objects (invention of the method)

\section{SUMMARY}

Thus, the methods of information processing, modeling of physical processes, and systems control may be protected as inventions in Russia and abroad with the conclusion of licensing agreements and receiving income from granting rights to use these inventions.

\section{CONCLUSIONS}

At present Russia as a participant of the global process of innovative economic development is improperly holding a low position among the other technologically advanced countries that does not comply with its high scientific and technical potential and is due to a small proportion of high-tech products in exports and a small volume of the IP market.

The IP market in Russia is less than $1 \%$ of the world market and holds only fractions of a percent of GDP. The main difference between patenting of inventions in Russia and in developed countries is observed in technologies. Computer technologies are patented in Russia much less intensely than, for example, in the United States, Japan and China. Meanwhile, development and supply of products in the field of information technology is becoming one of the most profitable items of the Russian export. Software protection in Russia is growing rapidly, but is executed within the frameworks of copyrights by registering computer programs and databases. At the same time, protection of inventions in information technology in the field of information processing, modeling of physical processes, and system control is much more promising for concluding licensing agreements and receiving income from granting rights to use these inventions.

\section{References}

1] Yu. Seliverstov, "Activating the involvement of intellectual property in economic circulation of Russian enterprises: theoretical and methodological and organizational aspects," Thesis for a degree of the Doctor of Sciences, Belgorod, 2013.

[2] G. Kuznetsova,"International trade intellectual property," Russian Foreign Economic Bulletin, vol. 8, pp. 35-47, 2013.

[3] Site WIPO. www.wipo.int

[4] OECD. Compendium of Patent Statistics. Paris: OECD, 2006.

[5] Z. Acs, D.B. Audretsch, "Patents as a measure of innovative activities," Kyklos, vol. 42, pp. 171-181, 1989.

[6] European Commission. Towards a European Research Area: Science, Technology and Innovation, Key Figures. Luxembourg: Office for Official Publications of the European Communities, 2005.

[7] European Commission. Commission Staff Working Document. Accompanying the Green Paper 'The European Research Area: New Perspectives' COM, 161, Brussels, 2007.

[8] G. Dosi, P. Llerena, V. Sylos Labini, "The relationships between science, technologies and their industrial exploitation: an illustration through the myths and realities of the so-called 'European Paradox," Research Policy, vol. 35, pp. 1450-1464, 2006.

[9] K. Smith, The Oxford Handbook of Innovation. Oxford: Oxford University Press, 2004.

[10] J. Fagerberg, M. Feldman, M. Srholec, "Technological Dynamics and Social Capability: Comparing U.S. States and European Nations," Paper no. 2011/11. Centre for Innovation, Research and Competence in the 
Learning Economy (CIRCLE), Lund University P.O., 2011, http://www.circle.lu.se/publications ISSN 1654-3149

[11] R. Crescenzi, A. Rodríguez-Pose, M. Storper, "The territorial dynamics of innovation: a Europe-United States comparative analysis," Journal of Economic Geography, vol. 7, issue 6, pp.673-709, 2007.

[12] The Global Innovation Index: Stronger Innovation Linkages for Global Growth. Soumitra Dutta, INSEAD - Editor, WIPO, ISBN: 978-29522210-2-3, 2012.

[13] P. M. Romer, "Endogenous Technological Change," Journal of Political Economy, vol. 98, pp. 71-102, 1990 .

[14] P. Aghion, P. Howitt, "A Model of Growth through Creative Destruction. Econometrica," vol. 60, pp. 323-351, 1992.

[15] Report "OECD Science, Technology and Industry Scoreboard 2011". Education at a Glance 2011: OECD Indicators, 2012.

[16[ A. Grammatchikov, "Cadres decide everything" Expert, vol. 14, pp. 1024, 2017. 